\title{
Affirmative Action and Electoral Reform
}

The elimination of racial barriers to voting and to voter registration has allowed racial minorities to achieve formal political equality. ${ }^{1}$ Blacks and Hispanics continue, however, to be significantly underrepresented in state and local legislative bodies relative to their numbers in the general population. ${ }^{2}$ In at-large elections, the dominant form of elections in United States cities, ${ }^{3}$ these racial minorities usually lack the numerical strength to ensure the election of minority candidates. ${ }^{4}$ Because of racial prejudice and the distinctness of minority interests, they frequently are unable to elect representatives by forming majority coalitions with other groups. ${ }^{5}$

This Note seeks to identify a constitutionally permissible method of increasing minority representation. It describes the current political underrepresentation of blacks and Hispanics and finds that existing remedies for discrimination in voting are inadequate to correct minority underrepresentation. The Note argues that states should make voluntary efforts to increase the representation of these racial minorities in state and local legislative bodies. The Note proposes that such voluntary reforms are justified by the goal of including all minorities in the political process. Unlike existing justifications for voluntary reform, the goal of political inclusion is both consistent with equal protection doctrine and sufficient to support thoroughgoing reform. Both gerrymandering district boundaries and

1. This Note defines formal political equality as universal equal suffrage for persons of voting age. See J. Still, Voter Equality in Electoral Systems 25-28 (May 1977) (unpublished Ph.D. thesis in Yale University Library).

2. Although a number of ethnic minorities, as well as women, are politically underrepresented, this Note focuses on the need to improve the representation of blacks, Mexican-Americans, and Puerto Ricans. Of the various ethnic minorities in the United States, these groups are the largest, see U.S. BUREAU OF THE CENSUS, DEP'T OF COMMERCE, CURRENT POPULATION REPORTS, POPULATION Characteristics, Series P-20, No. 350, POPUlation Profile OF THE UNited STATES: 1979, at 2 (1980) (25 million blacks, 7.3 million Mexican-Americans, and 1.7 million Puerto Ricans in United States) [hereinafter cited as POPULATION PROFILE], and are among the poorest, see id. at 42-43 (median family income $\$ 10,879$ for blacks, compared with $\$ 18,368$ for whites); U.S. BUREAU OF THE CENSUS, DEP'T OF COMMERCE, CURRENT POPULATION REPORTS, POPULATION CHARACTERISTICS, SERIES P-20, NO. 347, PERSONS OF SPANISH ORIGIN IN THE UNITED STATES: MARCH 1979, at 3 (adv. rep. 1979) (median family income $\$ 12,800$ for Mexican-Americans, and $\$ 8,300$ for Puerto Ricans). Moreover, these ethnic minorities have endured a long history of racial discrimination in the electoral sphere. See U.S. COMM. ON Givil RIGHTS, THE MEXICAN AMIERICAN 9, 222-23\% (1968) (describing use of language laws and physical intimidation to inhibit political participation by Mexican-Americans); U.S. COMMI. ON CIVIL RIGHTS, POLITICAL PARTICIPATION 1-10 (1968) (tracing history of black disenfranchisement).

3. See [1979] MUNiCipal Y. B. 99 (Int'l City Management Ass'n) (64\% of United States cities use at-large systems to elect city council members).

4. See p. 1813 infra (at-large elections lead to substantial underrepresentation of minorities).

5. See note 14 infra (minorities frequently unable to form biracial coalitions because of racial prejudice). 
adopting structural voting schemes, such as proportional and cumulative voting, can further the goal of political inclusion. Structural reforms are, however, the preferred method of reform because they are the most precisely tailored and least drastic means of implementing the political inclusion principle.

\section{The Persistence of Minority Underrepresentation}

Blacks and Hispanics are severely underrepresented in state and local legislative bodies because of racial discrimination and economic deprivation. These minorities would derive numerous benefits from improved representation at state and local levels. Federal statutory and constitutional provisions prohibiting racial discrimination in electoral systems do not successfully address the problem of minority underrepresentation. In order to increase the number of minority representatives, state and local governments should voluntarily reform existing electoral systems to facilitate the election of more blacks and Hispanics.

\section{A. The Need to Improve Minority Representation}

Blacks and Hispanics are underrepresented in state and local legislative bodies. ${ }^{6}$ Blacks hold approximately $50 \%$ of their proportionate share of city council seats. ${ }^{7}$ Hispanics have less than $45 \%$ of their share of city council representatives. ${ }^{8}$ Blacks and Hispanics are also seriously underrepresented in state legislatures. ${ }^{9}$ The underrepresentation of blacks and

6. Racial minorities are also underrepresented in the United States Congress. See CONG. Q. WEEKLY REP., Jan. 24, 1981, at 200 (no black senators and only 18 black representatives in 1981); M. LEVY \& M. KRAMER, THE ETHNIC FACTOR 74 (1972) (only six members of Congress are Spanish-speaking Americans). This Note does not address the underrepresentation of ethnic minorities in the United States Congress. Although many of the arguments in this Note apply to Congress as well as to state and local legislatures, efforts to increase the number of minority representatives in Congress would involve special problems. Given that each state elects only one senator in any single election, it is impossible to devise a system for electing senators who represent every large minority group living in a state. United States Representatives could be elected using multimember district systems that foster minority representation. It would be exceedingly difficult, however, to change the long-standing tradition of singlemember congressional districts.

7. See Jones, The Impact of Local Election Systems on Black Political Representation, 11 URB. AFF. Q. 345, 350-51 (1976) (blacks occupy 43\% of their proportionate share of city council seats in cities that employ at-large elections, and $61 \%$ in cities that use district systems); Karnig, Black Representation on City Councils, 12 URB. AFF. Q. 223, 226-27 (1976) (number of blacks serving on city councils represents only $53 \%$ of blacks' proportionate share).

8. See Taebel, Minority Representation on City Councils: The Impact of Structure on Blacks and Hispanics, 59 SOC. SCI. Q. 142, 145-46 (1978) (Spanish-speaking Americans have achieved $44 \%$ of their proportionate share of representatives on city councils).

9. See T. DYE, Politics IN STATES AND COMMUNITIES 123 (1973) (blacks seriously underrepresented in six of seven state legislatures studied). Americans of Spanish origin constitute $5.6 \%$ of the total population, see POPULATION PROFILE, supra note 2, at 2, yet fewer than $1.1 \%$ of all state legislators in the United States are of Spanish origin, see F. LEMUS, NATIONAL ROSTER OF SPANISH SURNAMED ELECTED OFFICIALS 316-409 (1973) (less than 80 state legislators in United States are of Spanish origin); COUNCIL OF STATE GOVERNMENTS, THE BOOK OF THE STATES, 1980-81, at 85 


\section{Minority Representation}

Hispanics in state and local legislative bodies is attributable to several factors. The use of at-large municipal elections is "the single most important variable" in explaining minority underrepresentation on city councils. ${ }^{10}$ Also, city councils with few members tend to include very few black and Hispanic representatives. ${ }^{11}$ In addition, the continuing economic deprivation these groups suffer ${ }^{12}$ limits their ability to mobilize the resources needed to conduct effective political campaigns. ${ }^{13}$ Finally, racial discrimination against these minorities hampers their ability to form coalitions with other groups. ${ }^{14}$

These racial minorities would benefit significantly from the election of more minority legislators. ${ }^{15}$ Minority representatives serve as spokesmen for the minority community, facilitating debate within minority ranks ${ }^{16}$ as well as expressing minority needs to the larger community. ${ }^{17}$ Minority

(1980) $(7,482$ state legislators in United States).

10. Berry \& Dye, The Discriminatory Effects of At-Large Elections, 7 FLA. ST. L. REV. 85, 11321 (1979) (regression analysis identified at-large system as most important variable explaining minority underrepresentation).

11. See Taebel, supra note 8 , at $148-49$ (smaller councils lead to significantly greater minority underrepresentation).

12. See note 2 supra (median family income of blacks, Mexican-Americans, and Puerto Ricans significantly less than that of whites).

13. See W. Mullen, Black Political Participation 100 (1972) (relative lack of financial resources hampers black efforts to obtain political power even where blacks constitute a sizeable proportion of the population); Note, Racial Vote Dilution in Multimember Districts: The Constitutional Standard After Washington v. Davis, 76 MICH. L. REV. 694, 718 n.122 (1978) (past employment discrimination limits number of minorities financially able to seek office or to support minority candidates).

14. See A. Campbell, P. Converse, W. Miller, \& D. Stokes, The AMERiCan Voter 166-67 (1964) (ethnic group membership affects voting independently of variables such as income and education); D. MATTHEWS \& J. PROTHRO, Negroes AND THE NEW SOUTHERN POLITICS 478-79 (1966) (many blacks in the South are a permanent political minority because whites refuse to form biracial coalitions); W. MULLEN, supra note 13, at 98 (majority of whites unwilling to vote for black candidates).

15. See TAN 16-20 infra (listing benefits of increased minority representation). There is disagreement, however, over whether a minority group has more influence when it constitutes a majority in only a few districts or when the group is a strong minority in many districts. See Wright v. Rockefeller, 376 U.S. 52, 57-58 (1964) (black plaintiffs and black intervenors disagreed over desirability of concentrating black voters in a few districts). Racial minorities can probably exert more influence over legislative outcomes by electing some minority legislators than by using their voting power to influence how nonminority representatives vote. See Jones, Black Officeholders in Local Governments of the South: An Overview, 2 POL. 49, 69 (1971) (black officeholders successful in insuring a more equitable share of government benefits for their constituents); $c f$. J. MCCARTHY, RACE AND POLITICAL ACTIV. ITY IN AN URBAN CONTEXT 38 (1968) (swing vote influence does not ensure "that the most progressive candidate on issues relevant to the Negro community is very progressive"); Wilson, The Negro in Politics, in AMERICAN ETHNIC POLITICS 217, $227-29$ (L. Fuchs ed. 1968) (blacks can exert influence as marginal vote in an election only if white voters are divided and blacks are uncommitted). But $c f$. Lineberry, Reform, Representation and Policy, 59 SOC. SCI. Q. 173, 175-76 (1978) (no studies have linked minority representation on city councils to greater allocation of municipal services to minority community).

16. See S. Verba, SMall Groups and Political Behavior 215 (1961) (leaders perform important function of encouraging participation in group decisionmaking).

17. See W. BELL, R. HILL, \& C. WRIGHT, PUBLIC LEADERSHIP 89 (1961) (ethnic group political leaders perform valuable "bridging function" by expressing minority aspirations to majority). 
members also serve a policing function within political bodies. ${ }^{18}$ In addition, the election of minority representatives encourages greater political consciousness and participation in the minority community. ${ }^{19}$ Finally, the election of more minority legislators would help to break down harmful stereotypes of racial minorities as apathetic, docile, and incapable of success. ${ }^{20}$

\section{B. The Inadequacy of Current Remedies for Racial Discrimination in Voting}

The Voting Rights Act of $1965^{21}$ was enacted to eliminate racial barriers to voting and voter registration. ${ }^{22}$ The Act prohibits the use of literacy tests and other devices that prevent minority voting and voter registration. ${ }^{23}$ Section 5 provides for federal review of state and local actions that affect the right to vote ${ }^{24}$ to ensure that they are not discriminatory in either purpose or effect. ${ }^{25}$

The Fifteenth Amendment and the equal protection clause of the Fourteenth Amendment prohibit the denial or abridgement of the right to vote because of race. ${ }^{26}$ These amendments have been used to strike down

18. The presence of minority legislators deters legislative discrimination by reminding representatives that minority needs deserve the same consideration as those of the majority. Minority representatives can also police racial abuses by public employees. See Campbell \& Feagin, Black Politics in the South: A Descriptive Analysis, 37 J. POL. 129, 154-55 (1975) (black Atlanta councilman stopped racial discrimination by city employees).

19. See Latimer, Black Political Representation in Southern Cities, 15 URB. AFF. Q. 65, 80-81 (1979) (black voter turnout increases substantially when blacks no longer submerged in majority win, at-large elections).

20. Stereotypes that depict racial minorities as inferior harm racial minorities in two ways. Whites who adopt such stereotypes are likely to discriminate against racial minorities. See J. LEviN, THE FUNCTIONS OF PREJUDICE 22 (1975) (derogatory stereotypes of Mexican-Americans encourage discrimination by justifying unequal treatment); cf. B. ADAM, THE SURVIVAL OF DOMINATION 30-33 (1978) (ethnic prejudice transmitted from one generation to next by stereotypes depicting minorities as inferior). In addition, stereotypes maligning racial minorities may adversely affect a minority's selfimage. See G. MARX, PROTEST AND PREJUDICE 69-70 (1967) (belief in stereotype that they are inferior induces apathy in blacks).

21. 42 U.S.C. $\$ \S 1971,1973-1973 b b-1$ (1976 \& Supp. III 1979).

22. See South Carolina v. Katzenbach, 383 U.S. 301, 315 (1966) (legislative purpose behind Act was to eliminate racial discrimination in voting).

23. 42 U.S.C. $\$ \S 1973 a-1973 h$ (1976 \& Supp. III 1979).

24. 42 U.S.C. \$ 1973c (1976). See D. HUNTER, FEDERAL REVIEW OF VOTING CHANGES 20-32 (1975) (listing changes in electoral systems subject to federal preclearance under $\S 5$ ).

25. See City of Rome v. United States, 446 U.S. 156, 172-73 (1980) (voting practice must not be discriminatory in either purpose or effect to receive preclearance under § 5); Beer v. United States, 425 U.S. 130, 131-33 (1976) (section 5 prohibits state from instituting changes in voting procedures unless it has obtained a declaratory judgment that changes are not discriminatory in purpose or effect).

26. U.S. CONST. amend. XV, $\S 1$ ("The right of citizens of the United States to vote shall not be denied or abridged by the United States or by any State on account of race . . .."); U.S. CONST. amend. XIV, $\S 1$ ("No state shall . . . deny to any person within its jurisdiction the equal protection of the laws.") 
the refusal to count votes, ${ }^{27}$ ballot box "stuffing, ${ }^{328}$ grandfather clauses, ${ }^{29}$ "white primaries," ${ }^{30}$ the gerrymandering of city boundaries, ${ }^{31}$ and minority vote dilution. ${ }^{32}$

Judicial enforcement of the Voting Rights Act and the Fourteenth and Fifteenth Amendments has dramatically increased levels of minority voter registration and voting. Between 1950 and 1970, the proportion of southern blacks registered to vote increased from one-fifth to two-thirds. ${ }^{33}$ Advances in minority voter registration have increased the number of blacks and Hispanics who vote..$^{34}$

This increase in minority voter registration and voting, however, has not effectively increased the number of elected black and Hispanic representatives. The Supreme Court has interpreted the Voting Rights Act to prohibit only those changes in electoral systems that cause a retrogression in minority representation. ${ }^{35}$ Moreover, fewer than ten states are subject to section 5 of the Act. ${ }^{36}$ All federal review under section 5 of the Act of state action affecting the right to vote may soon end; the Act will expire in

27. See United States v. Mosley, 238 U.S. 383,386 (1915) (failure to count votes denies right to vote).

28. See United States v. Saylor, 322 U.S. 385, 389 (1944) ("stuffing" ballot box violates right to vote).

29. See, e.g., Lane v. Wilson, 307 U.S. 268, 275-77 (1939) (grandfather clause allowing persons to register to vote only if they were registered as of a certain date violates Fifteenth Amendment); Guinn v. United States, 238 U.S. 347, 364-65 (1915) (grandfather clause violates Fifteenth Amendment).

30. See, e.g., Terry v. Adams, 345 U.S. 461, $469-70$ (1953) (primary held by private political organization that excludes blacks violates Fifteenth Amendment); Smith v. Allwright, 321 U.S. 649, 663-64 (1944) (democratic primary excluding blacks violates Fifteenth Amendment).

31. See Gomillion v. Lightfoot, 364 U.S. 339, 347 (1960) (redefinition of city boundaries to exclude blacks violates Fifteenth Amendment).

32. See White v. Regester, 412 U.S. 755, 765-70 (1973) (multimember districts that "cancel out or minimize the voting strength" of racial minorities violate equal protection).

33. See M. LEVY \& M. KRAMER, supra note 6, at 51 (1972) (number of voting age blacks registered to vote in South rose from $20 \%$ in 1952 to $67 \%$ in 1970). Since 1972 the proportion of eligible voters registered to vote has decreased slightly for whites, blacks, and Hispanics. See U.S. DEP'T OF COMMERCE, BUREAU OF THE CENSUS, GURRENT POPULATION REPORTS, POPULATION CHARACTERISTICS, SERIES P-20, No. 359, VOTING AND REGISTRATION IN THE ELECTION OF NOVEMBER 1980, at 3 (1980) (from 1972 to 1980, percentage of voting age population registered to vote decreased from $73 \%$ to $68 \%$ for whites, from $65 \%$ to $60 \%$ for blacks, and from $44 \%$ to $36 \%$ for persons of Spanish origin).

34. See U.S. DEP'T OF COMMERCE, supra note 33 , at 1 (84\% of registered blacks and $82 \%$ of registered persons of Spanish origin voted in 1980 election, compared with $89 \%$ of registered whites).

35. See Beer v. United States, 425 U.S. 130, 141-42 (1976) (redistricting plan that resulted in severe underrepresentation of blacks upheld because, for first time, "at least one and perhaps two" blacks might be elected to the city council). The nonretrogression principle has been criticized on the ground that it does not ensure representation for minorities in proportion to their numbers. See id. at 143 (White, J., dissenting) (section 5 should be interpreted to require that new electoral plan provide blacks with "roughly proportional" representation); cf. Freeman, Legitimizing Racial Discrimination Through Antidiscrimination Law: A Critical Review of Supreme Court Doctrine, 62 MINN. L. Rev. 1049, 1104-05 (1978) (nonretrogression principle immunizes preexisting black underrepresentation from judicial scrutiny).

36. See D. HUNTER, supra note 24, at 49 app. (Alabama, Alaska, Arizona, Georgia, Louisiana, Mississippi, South Carolina, Texas, and Virginia subject to requirements of $\S 5$ ). In addition, 54 counties and 40 towns in other states are subject to the requirements of $\S 5$. Id. 
$1982,{ }^{37}$ and it is possible that the Act will not be renewed. ${ }^{38}$

Judicial interpretation of the Fourteenth and Fifteenth Amendments has also limited their effectiveness in improving minority representation. In City of Mobile v. Bolden ${ }^{39}$ the Supreme Court held that an electoral scheme violates the equal protection clause of the Fifteenth Amendment only if it was adopted or retained with the intent to discriminate. ${ }^{40}$ The requirement that the plaintiff demonstrate that racial discrimination was a "motivating factor" in the decision"1 places a heavy burden on minorities challenging electoral schemes. ${ }^{42}$

Unless additional efforts are made to improve the ability of blacks and Hispanics to elect representatives, these minorities will continue to be severely underrepresented. Therefore, states should take affirmative steps to

37. 42 U.S.C. $\S 1973 \mathrm{~b}(1976)$.

38. See N.Y. Times, Apr. 8, 1981, § A, at 10, col. 3 (city ed.) (describing split in Senate over whether to renew Voting Rights Act).

39. 446 U.S. 55 (1980). In that case, black voters brought suit on the ground that the city's electoral system unconstitutionally diluted their votes. Mobile's three city commissioners were selected by majority vote in at-large elections. Id. at 59-60. Although blacks constituted over one-third of Mobile's population, no black had ever been elected to the city commission. Id. at 97-98.

40. Id. at 66. Four justices took the position that evidence of the subjective motives of state legislators was necessary to demonstrate the presence of discriminatory intent. Id. at 71-74, 74 n.21. Justice Stevens, concurring in the judgment, proposed that inquiry into motive should focus on the objective effects of a decision, and found that the circumstances in Mobile supported the use of an electoral system as common as that employed in Mobile. Id. at 90-92. The Mobile plurality also suggested that racial animus may be required to demonstrate racially discriminatory intent. $I d$. at $71 \mathrm{n} .17$. But see note 65 infra (criticizing animus intent test).

Prior to Mobile it was not necessary to show discriminatory intent to establish "minority vote dilution." See White v. Regester, 412 U.S. 755, 765-70 (1973) (discriminatory intent not explicitly required to establish vote dilution); Nevett v. Sides, 571 F.2d 209, 234 (5th Cir. 1978), cert. denied, 446 U.S. 951 (1980) (Wisdom, J., specially concurring) (proof of discriminatory purpose irrelevant under the Fifteenth Amendment); $c f$. Note, supra note 13, at 720-26 (vote dilution properly considered part of fundamental rights, not antidiscrimination, law). But see Eisenberg, Disproportionate Impact and Illicit Motive: Theories of Constitutional Adjudication, 52 N.Y.U. L. REV. 36, 75 (1977) (use of multimember districts in White may have been "tainted" by official racial discrimination in other voting areas).

41. A showing that discriminatory intent was a "motivating factor" in a decision shifts the burden of proof to the state to rebut the presumption of discriminatory action. See Village of Arlington Heights v. Metropolitan Hous. Dev. Corp., 429 U.S. 252, 270 n.21 (1977) (proof that decision was "motivated in part" by discriminatory purpose shifts burden to state to establish that same decision would have been reached had impermissible purpose not been considered); Washington v. Davis, 426 U.S. 229, 241 (1976) (prima facie case of discriminatory purpose shifts burden to state to show that racially neutral criteria produced decision).

42. Proving the subjective motivation of state officials is very difficult. See United States v. O'Brien, 391 U.S. 367, 384 (1968) (motive inquiry requires "guesswork"); Note, Reading the Mind of the School Board: Segregative Intent and the De Facto/De Jure Distinction, 86 YALE L.J. 317, 322-25 (1976) (theoretical and practical difficulties in subjective intent standard). In addition, plaintiffs frequently lack access to evidence of state officials' motives. See Perry, Modern Equal Protection: A Conceptualization and Appraisal, 79 CoLuM. L. REv. 1023, 1038 (1979) (defending party generally has readier, and sometimes exclusive, access to evidence of motivation). The intent standard itself creates an incentive for state officials to conceal their discriminatory conduct. See United States v. Texas Educ. Agency, 532 F.2d 380, 388 (5th Cir. 1976), vacated and remanded on other grounds sub nom. Austin Independent School Dist. v. United States, 429 U.S. 990 (1976) (state officials likely to pursue discriminatory practices "in ways that are devious, by methods subtle and illusive"). 
increase the representation of these racial minorities in state and local legislative bodies.

\section{Alternative Methods of Increasing Minority Representation}

State and local governments could adopt a variety of measures to increase the ability of blacks and Hispanics to elect their own representatives. Redistricting is one possible method of reform. ${ }^{43}$ Where members of a racial voting bloc are divided among numerous voting districts, it is unlikely that they will be able to elect a representative. Concentrating minority voters within a few districts would enhance their ability to elect a representative.

Another means of increasing minority representation would be to alter the method of electing representatives. First, a majority win requirement could be replaced with a rule that a candidate needs only a plurality of votes to be elected. ${ }^{44}$ Second, the number of seats in a district could be increased. ${ }^{45}$ Third, voters might be allowed to engage in single-shot voting. ${ }^{66}$ All of these reforms would enhance the ability of minority groups to elect their own representatives without the need to build coalitions with other groups.

Cumulative, limited, or proportional voting systems are also effective schemes for increasing the ability of minorities to elect representatives. Cumulative voting leads to increased minority representation because it allows voters to cast multiple votes for one candidate. ${ }^{47}$ Limited voting

43. See, e.g., R. DIXON, DEMOGRATIC REPRESENTATION 461 (1968) (discussing redistricting as a technique for increasing effectiveness of minority votes); Note, Compensatory Racial Reapportionment, 25 STAN. L. REV. 84, 103-04 (1972) (proposing standard that would permit benign racial redistricting if resulting district has minority population between $30 \%$ and $70 \%$ of total district population).

44. A majority win requirement is a barrier to minority representation because it allows only a majority of voters to elect a representative. See Graves v. Barnes, 343 F. Supp. 704, 725 (W.D. Tex. 1972), aff'd in part, rev'd in part, sub nom. White v. Regester, 412 U.S. 755 (1973) (majority win requirements "strengthen the majority's ability to submerge a political or racial minority in a multimember district").

45. See Jones, supra note 7, at 351-52 (increased number of seats correlates strongly with improved black representation on city councils in South and North Central regions); Taebel, supra note 8, at 147-49 (large council size dramatically improves Hispanic representation on city councils).

46. Single-shot voting allows minority voters to cast as few of their votes as they wish. If minority voters are not permitted to single-shot their votes, they may be forced to cast votes for nonminority candidates. See Derfner, Racial Discrimination and the Right to Vote, 26 VAND. L. REV. 523, 554 n.127 (1973) (preventing single-shot voting deprives minorities of political influence in elections).

In some states laws prohibiting single-shot voting have been struck down on equal protection grounds. See Dunston v. Scott, 336 F. Supp. 206, 213 (E.D.N.C. 1972) (no rational basis for applying anti-single-shot law to only some cities); Stevenson v. West, No. $72-45$ (D.S.C. Apr. 7, 1972) (anti-single-shot voting law violates equal protection). But see Gordon v. Meeks, 394 F.2d 3 (5th Cir. 1968) (per curiam) (anti-single-shot law upheld).

47. Sec, c.g., R. DIXON, supra note 43 , at 523 (cumulative voting enables minority groups larger than $25 \%$ of all voters to elect one of three representatives); E. LAKEMAN, HOW DEMOCRACIES VOTE 85-88 (1970) (discussing use of cumulative voting). 
systems facilitate minority representation by prohibiting voters from voting for each seat to be filled..$^{48}$ In a proportional voting system, voters must list the candidates in order of preference. ${ }^{49}$ Since each vote is counted for the first candidate on a voter's list who needs that vote in order to be elected, no votes are "wasted" on a candidate who already has a sufficient number of votes to be elected. Proportional voting schemes ensure that all groups sufficiently large to command at least one seat are represented in proportion to their voting strength.

\section{Judicial Review of Legislative Reforms to Increase Minority Representation}

Voluntary government plans that are adopted for the purpose of increasing minority representation will be challenged as violations of equal protection. ${ }^{50}$ In equal protection analysis, the court first determines whether there has been a sufficient showing of discrimination to establish a prima facie violation of equal protection. Both discriminatory intent and impact are necessary to violate the equal protection clause. ${ }^{51}$ The state may rebut a prima facie violation by demonstrating that the governmental action being challenged serves an important or compelling state interest. ${ }^{52}$

48. The more the vote is limited, the greater are minority opportunities to elect representatives. For example, in a four-seat district, if each voter has three votes, the minority must number threesevenths of all voters to elect one representative. If each voter is limited to two votes, the minority can elect a candidate if it exceeds one-third of the electorate. See E. LAKEMAN, supra note 47, at 80-84.

49. Proportional voting systems allow voters either to vote for one party or to indicate their preferences among the candidates of all parties. See E. LAKEMAN, supra note 47, at 105 . Under either system, the number of seats is divided by the total votes cast. The resulting "quota" is the number of votes that entitles a party or candidate to a seat. The first system requires that voters cast their ballots for a party's list of candidates. The votes a party receives are then used to elect that party's candidates in the order they appear on that party's list. Id. at 90-93. Under the second system, the "single transferable vote," voters may list candidates in order of preference. All voters who express the same preferences are proportionally represented. Id. at 109.

50. Two types of plaintiffs are likely to challenge race-conscious, voluntary government actions to increase minority representation. A challenge might be brought by members of the white majority whose representative strength has been reduced. $C$. Offermann v. Nitkowski, 378 F.2d 22 (2d Cir. 1967) (challenge by whites to voluntary desegregation plan to remedy de facto segregation). Also, minorities not benefited by a plan designed to assist another minority group may challenge the plan on the ground that it does not include them. See United Jewish Organizations v. Carcy, 430 U.S. 144 (1977) (challenge by Hasidic Jews to redistricting plan creating predominantly black districts).

51. See Ely, Legislative and Administrative Motivation in Constitutional Law, 79 YALE L.J. 1205, 1252 n.139 (1970) (equal protection violated by discriminatory intent "accompanied by only that quantum of impact it takes to vest standing"); cf. Washington v. Davis, 426 U.S. 229, 239-41 (1976) (discriminatory purpose needed in addition to disproportionate racial impact to violate equal protection). But cf. Gity of Richmond v. United States, 422 U.S. 358, 378-79 (1975) (annexation made for purpose of discriminating against blacks violates $\S 5$ of Voting Rights Act "whatever its actual effect"); note 70 infra (stigmatic harm satisfies impact requirement of equal protection). The Supreme Court arrived at the present standard for an equal protection violation by evolutionary steps. See Beer v. United States, 425 U.S. 130, 148 n.4 (1976) (Marshall, J., dissenting) (citing cases supporting conflicting propositions that only impermissible purpose, only impermissible effects, or either impermissible purpose or effects violates equal protection).

52. In traditional equal protection analysis, a governmental classification must serve a "compel- 
In order for the plan to be constitutional, the court must also find that the government action is precisely tailored to serve the asserted state interest, and that the government has selected the least drastic means available for achieving its purpose..$^{53}$

Courts have proposed two theories to support electoral reforms designed to increase minority representation that harm other groups. The first theory is that adoption of such reforms does not constitute actionable discrimination. ${ }^{54}$ The second theory is that efforts to improve minority represen-

ling" governmental interest to survive strict scrutiny. Regents of the Univ. of Cal. v. Bakke, 438 U.S. 265, 299 (1978) (Powell, J.); id. at 357 (Brennan, J., concurring in judgment in part and dissenting in part). Intermediate level scrutiny demands that the state action "substantially" serve an "important" governmental objective. Craig v. Boren, 429 U.S. 190, 197 (1976).

The Court has not explicitly decided which standard to apply in affirmative action cases. In Bakke, Justice Powell proposed that affirmative action plans be subject to strict scrutiny, 438 U.S. at 299, while Justices Brennan, White, Marshall, and Blackmun suggested that such plans need only satisfy the requirements of intermediate scrutiny, id. at 361 . In practice the Court has applied a standard of review in affirmative action cases that is less rigorous than traditional strict scrutiny . Compare Fullilove v. Klutznick, 100 S. Ct. 2758, 2795-97 (1980) (Marshall, J., concurring in judgment) (summary approval of minority business preference) and Bakke, 438 U.S. at 311-13 (Powell, J.) (state's interest in promoting academic diversity sufficient to uphold preferential admissions policy) with Loving $\mathrm{v}$. Virginia, 388 U.S. 1, 11 (1967) (traditional strict scrutiny of racial classification). An intermediate standard is appropriate in the affirmative action context given that political constraints will prevent adoption of all but the least controversial preferential programs. See Perry, supra note 42, at 1050.

53. See San Antonio Independent School Dist. v. Rodriguez, 411 U.S. 1, 16-17 (1973); Dunn v. Blumstein, 405 U.S. 330, 343 (1972). The requirement that the means be precisely tailored to serve the government objective applies to intermediate as well as to strict scrutiny. See Alevy v. Downstate Medical Center, 39 N.Y.2d 326, 336-37, 348 N.E.2d 537, 546, 384 N.Y.S.2d 82, 90 (1976) (intermediate scrutiny requires that no "less objectionable racial" means of serving affirmative action goals be available); Perry, supra note 42 , at 1045, 1048-49 (intermediate standard requires "any preferential program be designed to accomplish its objective in a manner that causes as little resentment as possible" among whites).

54. The paradigm for voluntary, non-remedial affirmative action by the state is the voluntary elimination of de facto segregation in public schools. Prior to Regents of the Univ. of Cal. v. Bakke, 438 U.S. 265 (1978), voluntary school integration plans were not subject to strict or intermediate scrutiny. See, e.g., Swann v. Charlotte-Mecklenburg Bd. of Educ., 402 U.S. 1, 16 (1971) (school authorities may prepare students to live in pluralistic society by prescribing for each school ratio of black to white students reflecting proportion for district as whole); Pride v. Community School Bd., 488 F.2d 321, 326-27 (2d Cir. 1973) (no court has applied strict scrutiny where state action has had effect and objective of reducing discrimination); Fuller v. Volk, 230 F. Supp. 25, 33-35 (D.N.J. 1964), vacated, 351 F.2d 323 (3d Cir. 1965) (desegregation of de facto segregated schools does not constitute racial discrimination against whites "of constitutional dimensions"). But see Norwalk CORE v. Norwalk Bd. of Educ., 423 F.2d 121, 124-25 (2d Cir. 1970) (Kaufman, J., dissenting) (voluntary busing to achieve school integration must be "scrutinized carefully"); Ely, The Constitutionality of Reverse Racial Discrimination, 41 U. CHI. L. REV. 723, 736 n.49 (1974) (rejecting argument that voluntary busing plans are not suspect because burden on individuals is "trivial").

Application of strict or intermediate scrutiny to affirmative action plans first gained support in the Supreme Court in the sex discrimination field. See Kahn v. Shevin, 416 U.S. 351, 358-59 (1974) (Brennan, J., dissenting) (intermediate level scrutiny appropriate for both programs designed to benefit women and sexual classifications disadvantaging women); id. at 361 (White, J., dissenting) (same). In Bakke, Justice Brennan stated that the voluntary desegregation cases recognized "racial pluralism" in schools as "a compelling social goal justifying the overt use of race." 438 U.S. at 363. Since Bakke, the state's interest in promoting integration has proven adequate to support race-conscious efforts to reduce de facto segregation despite application of strict scrutiny to such plans. See Johnson v. Board of Educ., 604 F.2d 504, 515-17, 515 n.5 (7th Cir. 1979), cert. granted, 100 S. Ct. 3055, vacated, 101 S. Ct. 339 (1980) (compelling state interest in integration sufficient to sustain voluntary state efforts to 
tation do constitute actionable discrimination, but are justified when they serve the important state interest of remedying past discrimination. The first theory is inconsistent with recent equal protection analysis, ${ }^{55}$ and the second, while constitutionally sound, has too limited an application to support widespread efforts to increase the number of minority representatives. Given the inadequacies of these theories, this Note proposes that the goal of including all minorities in the political process is an important state interest that supports affirmative action in the electoral sphere. This justification would support electoral reform even in the absence of a finding of past discrimination by the governing body.

\section{A. The Existence of Actionable Discrimination}

One theory that has been advanced to support the constitutionality of affirmative action in electoral reform is that adoption of a scheme to increase minority representation does not constitute actionable discrimination. This theory is erroneous because adoption of such a scheme is discriminatory in intent and produces a discriminatory harm.

The Supreme Court relied on the theory that affirmative action in electoral reform does not involve cognizable discrimination in United Jewish Organizations v. Carey (UJO). ${ }^{56}$ To comply with section 5 of the Voting Rights Act, the New York State Legislature adopted a redistricting plan to increase the number of nonwhite state legislators elected from parts of New York City..$^{57}$ In order to create "safe" nonwhite districts, state offcials divided a Hasidic Jewish community into two separate districts. ${ }^{58}$ The Hasidim argued that the plan diluted the value of their votes in order to achieve a racial quota in violation of the Fourteenth and Fifteenth Amendments.

Although the Court did not agree on any one rationale, ${ }^{59}$ a majority upheld the redistricting on the theory that it was not discriminatory. Jus-

slow white fight despite application of strict scrutiny); cf. Parent Ass'n v. Ambach, 598 F.2d 705, 719-20 (2d Cir. 1979) (minority students' choice of schools could be restricted in order to promote integration despite application of strict scrutiny).

55. See, e.g., Fullilove v. Klutznick, 100 S. Ct. 2758, 2781 (1980) (plurality opinion) (any racial preference must receive "searching examination"); id. at 2796 (Marshall, J., concurring in judgment) (remedial affirmative action plans must satisfy intermediate scrutiny); Regents of the Univ. of Cal. v. Bakke, 438 U.S. 265, 359 (1978) (Brennan, J., concurring in judgment in part and dissenting in part) (same); id. at 289-91 (Powell, J.) (all racial classifications merit strict scrutiny).

56. 430 U.S. 144 (1977).

57. Id. at 151-52.

58. Id. at 152.

59. Justice White's plurality opinion rested on both statutory and constitutional grounds. Justices Brennan and Blackmun joined in only that part of Justice White's opinion that rested on statutory considerations, while Justice Rehnquist joined in only the constitutional analysis. Justice Stevens joined in both parts of Justice White's opinion. Justice Stewart, joined by Justice Powell, concurred in the judgment. Chief Justice Burger dissented from the judgment, and Justice Marshall did not participate in the decision. 
tices White, Stevens, and Rehnquist found that no discrimination had taken place because the plan did not stigmatize any race. ${ }^{60}$ Furthermore, they argued that the plan did not deny the Hasidim "fair" representation because the redistricting would result in the election of white and nonwhite representatives in proportion to their numbers in the redistricted communities. ${ }^{61}$ Justice Stewart, speaking for himself and for Justice Powell, argued that the gerrymander had neither the purpose nor the effect of discriminating against whites. ${ }^{62}$ The purpose of the plan, he stated, was to comply with the Voting Rights Act, ${ }^{63}$ and the plan did not "undervalue" the political power of white voters. ${ }^{64}$

The conclusion that the redistricting plan in UJO did not result in discrimination ignores the discriminatory features of this type of reform. A legislature intentionally discriminates on the basis of race whenever it uses race as a decisionmaking criterion. ${ }^{65}$ In addition, a plan designed to help

60. 430 U.S. at 165.

61. Id. at 166. Justices White, Rehnquist, and Stevens argued that the redistricting plan was constitutional regardless of the fact that it had been adopted to comply with the Voting Rights Act. Even absent the Act, Justice White asserted, it would be constitutional for "a State in which a racial minority is unable to elect representatives from multimember districts to change to single-member districting for the purpose of increasing minority representation." Id. at 167.

62. Id. at $179-80$.

63. Id. at 180.

64. Id. at $179-80$.

65. See Fullilove v. Klutznick, 100 S. Ct. 2758, 2811 (1980) (Stevens, J., dissenting on other grounds) (equal protection clause imposes special obligation on courts to scrutinize race-conscious governmental decisionmaking because "procedural safeguards . . . play a vital part in preserving the impartial character of the legislative process"); Village of Arlington Heights v. Metropolitan Hous. Dev. Corp., 429 U.S. 252, 265-66 (1977) ("proof that a discriminatory purpose has been a motivating factor" in a decision triggers judicial scrutiny); Brest, The Supreme Court 1975 Term, Foreword: In Defense of the Antidiscrimination Principle, 90 HARV. L. REV. 1, 6-8 (1976) (all race-dependent decisions are presumptively irrational).

This presumption of irrationality extends to facially neutral laws that are race-dependent as well as to explicit racial classifications. See Personnel Adm'r v. Feeney, 442 U.S. 256, 272 (1979) ("ostensibly neutral" decisions that are race-dependent are presumptively invalid); Brest, supra, at 12-15 (facially neutral laws and decisions, if race-dependent, presumptively violate equal protection).

By contrast, the plurality in Gity of Mobile v. Bolden, 446 U.S. 55 (1980), suggested that racially discriminatory purpose is present only when a decision is made at least in part "because of" its "adverse effects upon an identifiable group." Id. at $71 \mathrm{n} .17$. The Court has mentioned this standard in earlier opinions. Sec, e.g., Personnel Adm'r v. Feeney, 442 U.S. 256, 279 (1979) (same language as in Mobile); Village of Arlington Heights v. Metropolitan Hous. Dev. Corp., 429 U.S. 252, 266 (1977) (decision motivated by "invidious discriminatory purpose" triggers judicial review). The view that state action based on race is subject to judicial scrutiny only if motivated by a desire to harm a racial group is inconsistent with other features of equal protection doctrine, see Perry, supra note 42, at $1037 \mathrm{n} .70$ (racial considerations that are not invidious sufficient to trigger judicial scrutiny), including the Court's treatment of affirmative action plans, see Regents of the Univ. of Cal. v. Bakke, 438 U.S. 265, 299 (1978) (Powell, J.) (official decisions that "touch upon an individual's race or ethnic background" trigger strict scrutiny); id. at 359 (Brennan, J., concurring in the judgment in part and dissenting in part) (remedial affirmative action plans must satisfy intermediate scrutiny). That racial discrimination is motivated by racial animus is highly probative that no legitimate state interest exists that will support the discrimination, but a plaintiff should not have to demonstrate racial animus in order to establish a prima facie violation of equal protection. 
one minority will often harm other minorities. ${ }^{66}$ Moreover, all race-dependent decisions and racial classifications encourage racial consciousness and animosity regardless of the purposes for which they are made. ${ }^{67}$

The race-conscious redistricting plan in UJO harmed the Hasidim in two ways. First, adoption of the plan decreased the effectiveness of the Hasidim's votes by depriving them of their ability to vote as a bloc. ${ }^{68}$ This was true even though the plan was designed to lead to the election of white and nonwhite representatives in proportion to their numbers in the community ${ }^{69}$ Second, adoption of the redistricting plan imposed a stigmatic harm on the Hasidim. ${ }^{70}$ The redistricting arguably caused the

66. See United Jewish Organizations v. Carey, 430 U.S. 144, 174 (1977) (Brennan, J., concurring) ("TT]he natural consequence of our governing processes [is] that the most 'discrete and insular' of whites often will be called upon to bear the immediate, direct costs of benign discrimination."); Kaplan, Equal Justice in an Unequal World: Equality for the Negro-The Problem of Special Treatment, 61 NW. U.L. REV. 363, 373-74 (1966) (preferential treatment for blacks most likely to burden Puerto Ricans, Mexican-Americans, and other minorities). The danger that a benign program might in fact be malevolent, or have malevolent effects, justifies thorough judicial examination of such programs. Cf. United Jewish Organizations v. Carey, 430 U.S. 144, 173 (1977) (Brennan, J., concurring) ("if judicial detection of truly benign policies proves impossible or excessively crude," perhaps all racial classifications should be invalidated).

67. See Kaplan, supra note 66 , at $379-80$ (use of racial criteria by state places educative force of government behind belief that race is relevant to individual worth); Perry, supra note 42, at 1044-45 (affirmative action plans that disadvantage whites stimulate racial resentment and hostility).

68. Courts have frequently held that changes in electoral systems that decrease an individual's chances of forming a successful electoral coalition constitute a cognizable constitutional injury. Sec, e.g., Gomillion v. Lightfoot, 364 U.S. 339 (1960) (exclusion of black voters from voting district violates Fifteenth Amendment); Kirksey v. Board of Supervisors, 554 F.2d 139 (5th Cir.) (en banc), cert. denied, 434 U.S. 968 (1977) (splitting black voters among several districts violates equal protection); cf. City of Mobile v. Bolden, 446 U.S. 55, 140 n.39 (1980) (Marshall, J., dissenting on other grounds) (requirement of discriminatory effect satisfied by showing that adoption of electoral scheme brought about retrogression in group's voting strength); Perkins v. Matthews, 400 U.S. 379, 388-89 (1971) (annexation of white communities dilutes black votes under Voting Rights Act).

69. There are at least two possible theories concerning what satisfies the impact requirement of equal protection. According to one theory, a discriminatory harm occurs when a race-dependent decision results in unequal treatment of blacks and whites. In Palmer v. Thompson, 403 U.S. 217 (1971), the Court upheld the closing of segregated municipal swimming pools despite allegations of illicit motive on the ground that the closing affected blacks and whites equally. Id. at 225. The Court limited this aspect of Palmer, however, in Washington v. Davis, 426 U.S. 229 (1976), by stating that neither discriminatory purpose nor effect was present in Palmer. Id. at 242-43.

An alternative theory, and the one this Note adopts, is that the impact requirement of equal protection is satisfied by showing that an individual is in a worse position than he or she would have been as a result of a race-dependent decision. This test is satisfied by a race-conscious decision that burdens an individual even if the decision burdens blacks and whites "equally" or creates a mechanism, such as an electoral system, that results in the "equal" treatment of blacks and whites. Cf. Loving v. Virginia, 388 U.S. 1, 8, 10-11 (1967) (statute forbidding miscegenation unconstitutional); Goss v. Board of Educ., 373 U.S. 683 (1963) (statute allowing students of any race to transfer to schools where their race is in the majority unconstitutional).

70. The redistricting plan in UJO may have been motivated by anti-Semitism, see Ely, supra note 54, at 737-38 (racial preferences that disproportionately burden Jews are presumptively invalid because likely to be motivated by anti-Semitism), and thus was likely perceived as anti-Semitic by both Jews and non-Jews. But see United Jewish Organizations v. Carey, 430 U.S. 144, 165 (1977) (plurality opinion) (redistricting plan in UJO "represented no racial slur or stigma with respect to whites or any other race").

Stigmatic harm is sufficient to satisfy the impact requirement of equal protection. See Brown v. Board of Educ., 347 U.S. 483, 493-95 (1954) (stigmatic harm sufficient to invalidate legally segre- 
Hasidim to feel that, compared to blacks, they were less worthy of government protection.

The plaintiff in UJO represented the members of an ethnic minority. White majority voters, however, would also have a valid equal protection claim if they were submerged in safe minority districts by redistricting. ${ }^{11}$ Legislative decisionmaking infected by racial considerations is discriminatory in intent regardless of whether the adversely affected group is in the minority. In addition, white majority voters submerged in safe minority districts suffer a discriminatory harm. Their votes are diluted because the group is deprived of its ability to vote effectively as part of a racial bloc.

In $U J O$ the legislature employed the technique of redistricting to increase minority representation. Any other type of scheme to improve minority representation, however, would also be discriminatory. ${ }^{22}$ Cumulative or proportional voting systems, for example, can improve the ability of minorities to elect representatives. Where these schemes replace majority win systems, it is unlikely that the majority will elect as many representatives as it could under the prior electoral system. This loss in ability to elect representatives is sufficient to support a prima facie violation of equal protection. ${ }^{73}$

\section{B. The Remedial Justification}

Assuming that adoption of electoral reforms to increase minority representation would constitute actionable discrimination, an important state interest is necessary to justify the reform. ${ }^{74}$ Voluntary efforts to increase minority representation may be justified on the theory that the state has an important interest in remedying the effects of past discrimination. ${ }^{75}$ The remedial justification can support a variety of strategies for increasing minority representation, including redistricting. ${ }^{76}$ In many states and cit-

gated schools); Brest, Palmer v. Thompson: An Approach to the Problem of Unconstitutional Legislative Motive, 1971 SUP. CT. REV. 95, 116 \& n.110 (member of minority group has cause of action if stigmatized by racially motivated decision that was "useful and fair").

71. See Fullilove v. Klutznick, 100 S. Ct. 2758, 2798 (1980) (Stewart, J., joined by Rehnquist, J., dissenting) (Constitution forbids racial discrimination "whatever the race may be of those who are its victims"); Regents of the Univ. of Cal. v. Bakke, 438 U.S. 265, 289-90 (1978) (Powell, J.) (persons of different color afforded same equal protection rights); id. at 359-61 (Brennan, J., concurring in judgment in part and dissenting in part) (affirmative action plans that burden whites are presumptively unconstitutional).

72. See pp. 1817-18 supra (describing effectiveness of various methods of increasing minority representation).

73. See note 68 supra (loss of ability to elect representatives satisfies impact requirement of equal protection).

74. See note 52 supra (discussing appropriateness of intermediate scrutiny standard).

75. See Regents of the Univ. of Cal. v. Bakke, 438 U.S. 265, 366 n.42 (1978) (Brennan, J., concurring in judgment in part and dissenting in part) (state's interest in remedying past discrimination sufficient to justify affirmative action).

76. See pp. 1817-18 supra (discussing various methods of increasing minority representation). 
ies, the remedial justification provides an adequate legal basis for increasing minority representation to appropriate levels.

The remedial justification is, however, a limited solution to the problem of minority underrepresentation. First, it can be invoked only if underrepresentation is the result of past discrimination by a state or local government. ${ }^{77}$ But minority underrepresentation is attributable largely to racially polarized voting. ${ }^{78}$ Thus, the remedial justification does not reach a major source of minority underrepresentation.

Second, state and local governments may not be competent to make the finding of past discrimination that supplies the predicate for legislative affirmative action under the remedial theory. The Supreme Court has suggested that by virtue of section 5 of the Fourteenth Amendment, Congress is the most competent of any government body to make findings of past discrimination. ${ }^{79}$ The Court has not yet decided whether state and local governments are less competent to make such findings. ${ }^{80}$

77. See Fullilove v. Klutznick, 100 S. Ct. 2758, 2800 (1980) (Stewart, J., joined by Rehnquist, J., dissenting) (minority set-aside unconstitutional because no evidence of past discrimination by Congress); id. at 2806-07 (Stevens, J., dissenting) (insufficient evidence of past discrimination in federal or federally funded programs to support remedial action); $c f$. id. at 2777 (plurality opinion) (Congress may condition grant of federal funds to states on requirement that states avoid discriminatory conduct that Congress could outlaw directly); id. at 2788 (Powell, J., concurring) (sufficient evidence of past "private and governmental discrimination" to uphold remedial set-aside). But see Regents of the Univ. of Cal. v. Bakke, 438 U.S. 265, 366 (1978) (Brennan, J., concurring in judgment in part and dissenting in part) (past "societal racial discrimination" can support remedial affirmative action). See generally The Civil Rights Cases, 109 U.S. 3 (1883) (state action required to invoke Fourteenth Amendment); N. DORSEN, P. BENDER, B. NEUBORNE, \& S. LAW, 2 EMERSON, HABER, \& DORSEN'S POLITICAL AND GIVIL RIGHTS IN THE UNITED STATES 386-422 (4th ed. 1979) (describing state action requirement). State inaction may also be discriminatory. See City of Mobile v. Bolden, 446 U.S. 55, 74 n.21 (1980) (plurality opinion) (raising possibility that Mobile's electoral system was retained for a discriminatory purpose); Brest, supra note 65 , at 14-15 ("racially selective indifference" can violate equal protection).

78. See note 14 supra (minorities are frequently unable to form biracial coalitions because of racial prejudice). Individuals who vote along racial lines do not violate the Fourteenth or Fifteenth Amendments. See United Jewish Organizations v. Carey, 430 U.S. 144, 167 (1977) (plurality opinion). But see Perry, The Disproportionate Impact Theory of Racial Discrimination, 125 U. PA. L. REV. 540, 570-71 (1977) (multimember district system used by voters "as a vehicle of racial discrimination" becomes "infected with discriminatory purpose" and violates equal protection).

79. In Fullilove v. Klutznick, $100 \mathrm{~S}$. Ct. 2758 (1980), the Court placed considerable emphasis on $\S 5$ of the Fourteenth Amendment to support Congress' power to enact the minority set-aside program. Chief Justice Burger found that, since the Constitution expressly charges Congress with the "competence and authority to enforce equal protection guarantees," Congress has the most comprehensive remedial power of any "organ of government, state or federal." Id. at 2777. In a concurring opinion, Justice Powell also emphasized Congress' "unique constitutional power" to enforce the Fourteenth Amendment. Id. at 2786.

80. In Regents of the Univ. of Cal. v. Bakke, 438 U.S. 265 (1978), Justice Brennan found that states as well as Congress could adopt race-conscious programs to remedy past discrimination. Id. at 366. In addition, Justice Brennan argued that the State of California could delegate this responsibility to the Board of Regents. Id. at 366 n.42. Justice Powell, on the other hand, stated that the University was incompetent to make findings of past discrimination. Id. at 309.

One interpretation of Justice Powell's competence test is that only Congress can make findings of past discrimination. Cf. Comment, Beyond Strict Scrutiny: The Limits of Congressional Power to Use Racial Classifications, 74 Nw. U.L. REV. 617, 644-45 (1979) ("[S]ection five of the fourteenth 


\section{Minority Representation}

Third, the remedial justification only supports those electoral reforms that are necessary to remedy the past discrimination. A remedial plan will be struck down if it is overinclusive or if a less drastic means of achieving the remedial purpose is available. ${ }^{81}$ For example, a change in the racial mix of electoral districts or in the method of electing representatives might be an overinclusive means of remedying past discrimination in voter registration. Alternatively, a court might find that a state-supported minority voter registration drive would be a less drastic means for achieving the remedial purpose.

\section{An Alternative Important State Interest: Including Minorities in the Political Process}

In light of the deficiencies of current rationales for affirmative action in the electoral sphere, a new justification is required to defend such reforms. This Note proposes that the goal of including all minorities in the political process is an important state interest that supports electoral reform to increase minority representation.

The inclusion of minorities in the political process was an important goal of the founding fathers. They designed our constitutional system to encourage political pluralism and to protect minority interests from the tyranny of the majority. According to Madison, the existence of numerous factions in the legislature makes it "less probable that a majority of the whole will have a common motive to invade the rights of other citizens . . . ."82 The separation of powers doctrine and the division of authority between the federal and state governments were intended to ensure that minority interests would continue to have a voice in government

amendment enables Congress to accomplish affirmative action goals that are denied to the states.") Another interpretation of Powell's standard is that only certain subdivisions of state government are incompetent to make findings of past discrimination. This interpretation views local legislative bodies (or boards of regents) as less competent than state legislatures on the ground that the former lack the resources and experience to make trustworthy determinations about past discrimination. Either interpretation of the competence test is open to criticism. See Wright, Color-Blind Theories and ColorConscious Remedies, 47 U. CHI. L. REV. 213, 229-30 (1980) (education professionals most competent to design remedies for past discrimination in education); The Supreme Court, 1979 Term, 94 HARV. L. REV. 75, 134-35 (1980) (equal protection limitation imposed on states "substantially equivalent" to that imposed on Congress).

81. See Fullilove v. Klutznick, 100 S. Ct. 2758, 2779-80 (1980) (plurality opinion) (minority setaside program would be unconstitutional without provision for administrative rebuttal of presumption that minority contractors had suffered from discrimination); cf. Regents of the Univ. of Cal. v. Bakke, 438 U.S. 265, 377-78 (1978) (Brennan, J., concurring in judgment in part and dissenting in part) ("categorical means" of dispensing benefits may be used when case-by-case inquiry into past discrimination is "impossible or extremely impractical").

82. THE FEDERALisT No. 10 at 83 (Mentor ed. J. Madison). Madison believed that the use of representative government in a country as large as the United States would guarantee the existence of many factions in the national government. See id. ("Extend the sphere and you take in a greater variety of partics and interests ....") 
decisionmaking. ${ }^{83}$

Including minorities in the political process strengthens our political system. The presence of minority legislators who can vote on and monitor legislative actions increases the legislature's responsiveness to minority interests. ${ }^{84}$ Thus, legislative decisions will more accurately reflect the interests of all members of society. The perception that their interests are represented in the legislature will enhance minority identification with their government and lead to greater acceptance of governmental action. ${ }^{85}$

The goal of including minorities in the political process supports increased representation for all minorities. Thus, state efforts to reallocate political power from one minority to another would be inconsistent with the goal of political inclusion. ${ }^{86}$ Reducing majority representation in order to achieve greater minority representation, however, would be consistent with this principle.

\section{Implementation of the Goal of Political Inclusion}

Both redistricting and structural electoral reforms are designed to open the political process to all minorities. They are intended to allow minorities above a certain minimum size to elect their own representatives and can enhance the ability of all minorities to form effective electoral coalitions. Hence, both types of electoral schemes satisfy the requirement of equal protection review that the challenged government action serve an important state interest.

Although both redistricting and structural electoral reforms may effectively increase minority representation, the latter represent a more precisely tailored and less drastic method of implementing the political inclusion principle than redistricting. Thus, structural reforms are the only permissible government strategy for increasing the number of minority

83. See J. ELY, DEMOCRACY AND DISTRUST 80 (1980) (by breaking up government authority among the three branches of the national government as well as between the federal and state governments, the Constitution attempts to prevent any one faction from obtaining "sufficient clout to be able to tyrannize others"').

84. See J. S. MILL, Considerutions on Representative GOVERNMENT 215 (New York 1862) ("To be under the eyes of others-to have to defend one's self to others-is never more important than to those who act in opposition to the opinion of others, for it obliges them to have a sure ground of their awn.")

85. Cf. note 19 supra (minority political participation increases when minorities no longer submerged in at-large elections).

86. Furthermore, no criteria exist to guide efforts to redistribute political power among different disadvantaged minorities. The concept of "discrete and insular minorities," see United States v. Carolene Prod. Co., 304 U.S. 144, 152 n.4 (1938), refers to all insular minorities and does not identify degrees of insularity. Nor does the legislative history of the Fourteenth Amendment identify a hierarchy of protected racial minorities. It is unclear what rights the framers of the Fourteenth Amendment sought to secure for blacks. See Perry, supra note 42, at 1025-28 (Fourteenth Amendment may have been meant to constitutionalize only specific provisions of the Civil Rights Act of 1866). 
representatives. Although some of the structural reforms discussed in this Note have not been commonly employed in the United States, their adoption would not have adverse effects on our political system.

\section{A. Alternative Means of Implementing the Goal of Political Inclusion}

In order to survive scrutiny under the equal protection clause, a challenged government action must be precisely tailored to serve an important state interest and must represent the least drastic means available for achieving the government's purpose. ${ }^{87}$ Structural electoral reforms such as proportional and cumulative voting best meet those requirements. Since state and local governments can always adopt structural reforms rather than redistrict, redistricting is never a constitutionally permissible method of furthering the political inclusion of minorities.

\section{Redistricting}

Increasing minority representation through race-conscious redistricting sometimes will fail to serve the important state interest of including minorities in the political process. Ethnic minorities commonly live in proximity to each other. ${ }^{88}$ Hence, individuals submerged in districts made safe for one minority are likely to be members of another minority. Decreasing one minority's representation in order to increase the representation of another minority violates the principle of political inclusion. ${ }^{89}$

Even if a redistricting plan satisfies the principle of political inclusion, it is not the most appropriately tailored method of increasing minority representation. First, redistricting is an underinclusive means of achieving this goal. Given that some minimum voting strength is required to carry a district, redistricting cannot benefit very small minority groups. In addition, redistricting is not a suitable means of increasing the representation of minorities that are dispersed throughout a community. ${ }^{90}$ It is virtually

87. See note 53 supra (both strict and intermediate standards require state to use least burdensome and most narrowly drawn means of furthering its goal).

88. Sce L. GRebler, J. MOORE, \& R. GUZMAN, The MEXICAN-AMERICAN PEOPLe 274-79 (1970) (study of 35 central cities in the Southwest found significant residential integration between Hispanics and blacks, Hispanics and Orientals, and Hispanics and American Indians); cf. U.S. BU. REAU OF THE CENSUS, DEP'T OF COMMERCE, CURRENT POPULATION REPORTS, SPECIAL STUdIES, P23 SERIES, NO. 49, POPULATION OF THE UNITED STATES 93 (1974) (81\% of blacks, 85\% of MexicanAmericans, and $98 \%$ of Puerto Ricans live in urban areas). But see Los Angeles Times, June 14, 1981, § II (Metro), at 1, col. 4 ("In Los Angeles County, Latinos and blacks are as segregated from each other as they are individually from whites.")

89. See p. 1826 supra (inclusion principle does not support reallocation of political power from one minority to another). A remedial justification, however, can support such reforms. See United Jewish Organizations v. Carey, 430 U.S. 144, 160-62 (1977) (plurality opinion).

90. Mexican-Americans, for example, tend to be dispersed, see L. GREBLER, J. MOORE, \& R. GUZMAN, supra note 88, at 274-75 (in Southwest and West residential patterns for Hispanics are more dispersed than for blacks), and thus redistricting plans may not aid them. See Taebel, supra note 
impossible for a redistricting scheme to form safe districts out of geographically scattered individuals. Moreover, individual minority members who are excluded from safe minority districts have no effective voice in determining who will represent the minority community.

Racial gerrymandering of district lines also encourages racial conflict and consciousness and therefore is not the least drastic means of furthering the goal of political inclusion. Racially safe districts reinforce minority group isolation by physically segregating voters according to race. Districting encourages voting along racial lines because voters in safe districts have little incentive to form coalitions with members of other groups. Thus, racially safe districts discourage political association and compromise among racial groups. ${ }^{91}$ In addition, the harsh and unequal burdens redistricting imposes on members of the majority foster resentment of affirmative action. Majority members submerged in safe minority districts become a new powerless minority while other majority voters may suffer little, if any, loss in the effectiveness of their votes. ${ }^{92}$

\section{Structural Reforms}

Adoption of a variety of structural voting reforms would best further the goal of including all minorities in the political process. Structural reforms such as adopting plurality win requirements or single-shot, cumulative, limited, or proportional voting systems ${ }^{93}$ are the most precisely tailored and least drastic means of enhancing minority representation. These types of reforms should be the exclusive means of furthering the goal of political inclusion.

First, structural schemes are unlikely to be underinclusive. Any minority group present in sufficient numbers has the opportunity to elect its own representative, even if the group is dispersed throughout the community ${ }^{94}$ Although certain minority groups may include so few members that they will not be able to elect their own representative, their ability to form

8, at 151 (" $[\mathrm{A}]$ geographical system of representation, such as the district system, may not materially benefit hispanics.").

91. See United Jewish Organizations v. Carey, 430 U.S. 144, $172-73$ (1977) (Brennan, J., concurring) (racially safe districts may frustrate "potentially successful efforts at coalition building across racial lines").

92. In United Jewish Organizations v. Carey, 430 U.S. 144 (1977), for example, the redistricting plan did not reduce the number of non-Hasidic white legislators likely to be elected. Id. at 163 . Unequal distribution of the burdens of affirmative action may also violate the requirement that the state use the least drastic means of accomplishing its goal. See Fullilove v. Klutznick, 100 S. Ct. 2758, 2793 (1980) (Powell, J., concurring) (race-conscious remedies permissible only if burden on "innocent third parties" sufficiently "limited" and "dispersed" to be consistent with "fundamental fairness").

93. See pp. 1817-18 supra (describing structural methods of increasing minority representation).

94. Single-member districts are not necessary to maintain group cohesion. See Parenti, Ethnic Politics and the Persistence of Ethnic Identification, 61 AM. POL. SCI. REV. 717, 721 (1967) (residential segregation not prerequisite for existence of ethnic "sub-societal structure"). 
effective electoral coalitions will be enhanced.95 Furthermore, because structural reforms do not submerge any minority voters in the safe districts of another group, they enhance the ability of all individual members of minority groups to elect their own representatives or to form decisive coalitions.

Second, structural electoral reforms are a less drastic means of improving minority representation. Although structural reforms facilitate racial bloc voting by reducing the number of voters who need to vote together to elect a candidate, they do not encourage it to the same degree as redistricting. Proportional and cumulative voting do not discourage voters from forming biracial coalitions. In addition, if racial bloc voting decreases, structural reforms allow voters to coalesce freely, whereas racially safe districts permanently discourage biracial coalition building. Moreover, structural reforms minimize majority resentment of affirmative action by equitably distributing the burdens of electoral reform. Majority members share the burden of structural reforms equally; no members of the majority are submerged in safe minority districts.

\section{B. Objections to Structural Reform}

Several of the electoral devices supported by the principle of political inclusion-including a large number of seats per district, plurality win requirements, and single-shot voting-are already used by some states and municipalities. ${ }^{96}$ Governments can adopt these mechanisms without making major changes in existing electoral systems. Cumulative, limited, and proportional voting systems are not, however, common in this country. ${ }^{97}$ Some critics contend that states should not institute such reforms because they would adversely affect our political system. These critics argue that such systems are too complicated for voters to exploit effectively and that

95. Replacing a majority win system with a proportional or plurality win system, for example, will reduce the number of voters who need to vote together to elect a candidate. This will allow even a small minority group to form successful coalitions with other voters more easily. Where a district plan is in effect and minorities are submerged in each district, change to a proportional or cumulative plan would increase the responsiveness of candidates to all minorities. If districts are highly competitive and minorities occupy a decisive swing vote position, minorities may already be maximizing the effectiveness of their votes and hence reform would be inappropriate. The swing vote influence of minorities, however, can be quite limited. See note 15 supra (minorities frequently lack prerequisites for effective swing vote power).

96. See [1979] MUNICIPAL Y. B., supra note 3, at 100 (over one-third of mayor-council cities have councils of more than ten seats); Graves v. Barnes, 343 F. Supp. 704, 725 (W.D. Tex. 1972), af'd sub nom. White v. Regester, 412 U.S. 755 (1973) (majority win requirements "[v]irtually unknown outside the South"); note 46 supra (anti-single-shot voting laws struck down in some states).

97. See R. DIXON, supra note 43, at 521-26 (limited, cumulative, and proportional voting have been used in only a few cities and states). Outside of the United States, however, proportional representation has been used extensively in national elections. See E. LAKEMAN, supra note 47, at 257-61 (listing foreign countries that use proportional systems). 
these reforms would undermine our political stability. ${ }^{98}$

Proportional and limited voting systems are not too difficult for voters to understand, however. A proportional list system merely requires voters to list the candidates in order of preference. ${ }^{99}$ The only unconventional task a limited voting system requires of voters is that they decide whether to cast all of their votes, since their votes for some candidates may help to defeat others for whom they voted. ${ }^{100}$ Once voters learn that they need not cast all of their votes, they can easily avoid this possibility. ${ }^{101}$

Cumulative voting systems are not difficult for voters to employ. To take maximum advantage of a cumulative system, a group should nominate exactly the number of candidates it can elect. ${ }^{102}$ Minority political leaders can determine the proper number of candidates once minority group voting strength is known. Minority group voting strength can usually be determined from the size of the minority population. ${ }^{103}$ Once a group has nominated the correct number of candidates, it must allocate its votes as equally as possible among its candidates. Because a minority group normally will nominate a limited number of candidates, minority voters will frequently be able to cast all of their votes for one candidate or to divide their votes equally between two candidates.

Voting systems that improve minority representation will not destabilize our political system by undermining the two-party system. Adopting a system of proportional representation, for example, would probably not cause an increase in the number of political parties. Most Western European countries adopted proportional representation systems early in this century. ${ }^{104}$ The change was not followed by a marked increase in the

98. See, e.g., F. HERMENS, DEMOCRACY OR ANARCHY? 398-99 (1941) (proportional representation too technical for voters); Lipset, Party Systems and the Representation of Social Groups, in Politicsl Parties 40, 56-57 (R. Macridis ed. 1967) (United States would have developed numerous political parties if proportional representation had been adopted in national elections); $M$. DUVERGER, L'INFLUENCE DES SYSTÈMES ÉLECTORAUX SUR LA VIE POLITIQUE 17-21 (1950) (proportional representation perpetuates existence of multiple parties and fragments existing political parties).

99. See note 49 supra (discussing use of proportional voting). Voters have encountered no special difficulties in areas where proportional representation has actually been employed. See E. LAKEMAN, supra note 47, at 143-50 (electorate has effectively used proportional representation schemes wherever implemented).

100. See pp. 1817-18 supra (discussing use of limited voting).

101. The need for this strategic decision is avoided entirely if the number of minority sandidates equals the number of votes each voter may cast.

102. See E. LAKEMAN, supra note 47 , at $87-88$ (nomination of too many candidates in a cumulative system weakens a group's voting strength).

103. Because of the prevalence of minority bloc voting, see Pettigrew, Black Mayoral Campaigns, in URBAN GOVERNANCE AND MINORITIES 14, 21 (H. Bryce ed. 1976) (many black constituencies highly loyal to black candidates), minority group voting strength can be determined if minority political leaders know the number of registered minority voters in the community and can estimate the level of minority voter turnout.

104. See E. LAKEMAN, supra note 47, at 161 (seven of eight European countries using majority win systems prior to World War One later adopted proportional representation). 


\section{Minority Representation}

number of parties in any of the countries. ${ }^{105}$ Nor has cumulative voting eroded the two-party system in Illinois, where cumulative voting has been used in state elections since $1872 .{ }^{106}$ Cumulative voting has consistently produced a working majority in the Illinois State House of Representatives. ${ }^{107}$

Even if the adoption of electoral schemes designed to increase minority representation did lead to a proliferation of political parties, it is not clear that this result would be undesirable. Coalition governments provide more continuity in policy than do majority systems because one election is unlikely to turn the entire government out of office. ${ }^{108}$ In addition, the interests of minority parties are more secure if consensus is reached in the legislature rather than through the electoral process. ${ }^{109}$

Critics of electoral systems that foster minority representation also argue that it is undesirable to grant a potential legislative voice to singleissue extremist political minorities. ${ }^{10}$ There is no clear harm to allowing the election of such extremist candidates, however. Their views may be irritating to the majority but they are unlikely to achieve great voting strength. Furthermore, the appeal of any single-issue extremist candidate is unlikely to continue over a long period. Unlike racial minorities, whose shared history of deprivation and discrimination has produced a strong sense of group identity, ${ }^{111}$ voters unified around a single issue are unlikely to be so concerned about that issue that they will forego expressing their views on all other issues in every election.

\section{Gonclusion}

State and local governments should reform existing electoral systems in order to increase the number of minority representatives in state and local legislative bodies. Including minorities in the political process is an important state interest that provides an expansive justification for electoral re-

105. In fact, the number of parties declined in some countries. Id.

106. R. DIXON, supra note 43 , at 532 .

107. See G. BLAIR, CUMULATIVE Voting 102-03 (1960) (since 1913, every election has produced a clear majority party).

108. E. LAKEMAN, supra note 47 , at 166.

109. See note 84 supra (public scrutiny of decisionmaking encourages outcomes sensitive to minority interests).

110. See, e.g., R. STRAETZ, PR POLITICS IN CINCINNATI 201-22 (1958) (perennial charge against use of proportional representation in Cincinnati municipal elections was that it encouraged "radicalism, left-wingism, and . . Communism"); Zeller \& Bone, The Repeal of P.R. in New York City-Ten Years in Retrospect, 42 AM. POL. SCI. REV. 1127, 1133 (1948) (charge in campaign to eliminate proportional representation in New York City council elections was that it encouraged the election of Communists and fascists); cf. F. HERMENS, supra note 98, at 145-300 (arguing that proportional representation contributed to rise of fascism in Italy and Germany).

111. Sec, e.g., A. CAMPBell, P. CoNVerse, W. Miller, \& D. STOKeS, supra note 14, at 170 (blacks most politically cohesive of all ethnic and interest groups surveyed); note 103 supra (black constituencies frequently loyal to black candidates). 
form. Governments should accomplish reform by altering the method of electing representatives, not by gerrymandering district boundaries. Such structural reforms are an appropriately tailored method of furthering the state's interest in providing all minorities with an opportunity for effective political participation. 